\author{
dr Barbara JAROS \\ Instytut Ekologii Terenów Uprzemysłowionych \\ email: bjaros@ietu.katowice.pl
}

DOI: 10.15290/ose.2016.03.81.10

\title{
ZRÓWNOWAŻONA KONSUMPCJA W PRAKTYCE. RAPORT Z BADAŃ
}

Streszczenie

W artykule przedstawiono wyniki badań ankietowych przeprowadzonych na potrzeby pracy doktorskiej autorki referatu pt.: Koncepcja zrónnoważonej konsumpcji - problemy implementacji w Polsce. Badania stanowily empiryczną ilustrację realizacji zasad zrównoważonej konsumpcji na przykładzie zachowań konsumpcyjnych dorosłej populacji mieszkańców województwa śląskiego. Kwestionariusz badawczy składał się z czterdziestu pytań pogrupowanych w czterech blokach tematycznych, tj.: konsumpcja żywności, konsumpcja związana z wyposażeniem i utrzymaniem mieszkania, konsumpcja związana z wykorzystaniem transportu, ogólne zagadnienia dotyczące konsumpcji. Badania ankietowe były próbą zasygnalizowania pewnych problemów, które wiążą się z konsumpcją gospodarstw domowych, posłużyły podkreśleniu wagi instrumentów ekonomicznych, informacyjno-edukacyjnych oraz regulacyjno-prawnych w kształtowaniu zrównoważonej konsumpcji, jak również ukazaniu zapatrywań mieszkańców województwa śląskiego w tym obszarze.

Słowa kluczowe: zrównoważona konsumpcja, zrównoważone i niezrównoważone zachowania konsumpcyjne

\section{SUSTAINABLE CONSUMPTION IN PRACTICE. SUMMARY OF RESEARCH FINDINGS}

\section{Summary}

The paper presents the results of a survey conducted for the author's $\mathrm{PhD}$ dissertation:The concept of sustainable consumption - problems of implementation in Poland. The survey was an empirical illustration of the implementation of principles of sustainable consumption on the example of the consumers' behavior - an adult population of the Silesian Voivodeship.The research questionnaire consisted of forty questions grouped in four thematic areas: food consumption, consumption associated with the equipment and maintenance of households, consumption associated with the use of transport and the general issues of consumption. The survey was an attempt to indicate some of the problems that are associated with the consumption in households - it stressed the importance of economic, regulatory and social instruments in the development of sustainable consumption and also showed the views of citizens of the Silesian Voivodeshipin this area.

Key words: sustainable consumption, sustainable and unsustainable patterns of behaviour

JEL: D12 


\section{Wstęp}

Zgodnie z definicją zrównoważonej konsumpcji, oznacza ona: taki proces korzystania z dóbr i ustug, który zaspokaja podstawowe potrzeby iprzynosi lepsza jakość zycia wraz z równoczesnym obniżaniem zusycia zasobów naturahych, materiatón toksycznych oraz emisji odpadón $i$ zanieczysz-

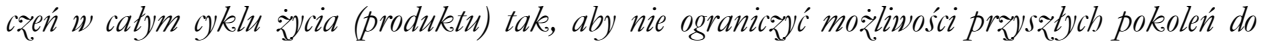
zaspokojenia własnych potrzęb [Oslo Rountable..., 1994]. Zdaniem D. Kiełczewskiego, zrównoważona konsumpcja to taka, która jest zrównoważona w kilku ważnych aspektach, tj.: ekonomicznym, ekologicznym, społecznym, psychologicznym, demograficznym, przestrzennym oraz intertemporalnym. Aspekt ekonomiczny wiąże się z ustaleniem właściwych proporcji między konsumpcją bieżącego pokolenia a konsumpcja przyszłych pokoleń; aspekt ekologiczny oznacza wybieranie takich form konsumpcji, które są możliwie najmniej uciążliwe dla środowiska oraz maksymalizowanie użyteczności konsumpcji wraz z równoczesnym zachowaniem użyteczności i jakości zasobów naturalnych i środowiska przyrodniczego; aspekt społeczny uznaje, że wszyscy ludzie mają równy dostęp do dóbr, w tym przede wszystkim do dóbr społecznie pożądanych; aspekt psychologiczny określa, że konsumpcja przyczynia się do wzrostu jakości życia oraz ustalenia równowagi między dobrobytem a dobrostanem; aspekt demograficzny głosi, że uwarunkowania demograficzne nie stanowią trwałej bariery wzrostu konsumpcji; aspekt przestrzenny uwzględnia to, że społeczeństwo zaspokaja potrzeby konsumpcyjne w sposób niełamiący zasad ładu przestrzennego; wreszcie aspekt intertemporalny wyraża się w tym, że wszystkie powyżej wymienione aspekty zrównoważonej konsumpcji będą możliwe do zrealizowania także w przyszłości [Kiełczewski, 2008, s. 61]. Należy nadmienić, że ta obszerna definicja praktycznie uwzględnia wszystkie cechy rozwojowe zrównoważonej konsumpcji, w szczególności jej cel nadrzędny - jakość życia. Pojęcie zrównoważonej konsumpcji można również definiować w konwencji zintegrowanego obrazowania w konsumpcji zasad odzwierciedlających trzy cechy rozwojowe nowego paradygmatu rozwoju, jakimi sa: trwałość, zrównoważenie oraz samopodtrzymywanie, tak jak to dokonuje się w przypadku rozwoju zintegrowanego [Borys, 2014, s. 9-10].

W zrównoważonej konsumpcji przez lepszą jakości życia rozumie się tzw. zrównoważoną jakość życia. Jej zapewnienie oznacza całkowite docenianie trzech sfer jakości życia, do których zalicza się:

- sferę materialna - jakość typu „mieć”;

- sferę psychiczna, emocjonalno-mentalną - jakość typu „być”;

- sferę duchową, sferę uczuć - jakość typu „kochać” [Allardt, 1993, s. 89-91].

Jak stwierdziła B. Kryk, jeżeli powyżej wymienione sfery pozostają ze sobą w równowadze, to możliwe jest osiagnięcie stanu harmonii zbliżonego do ideału (równowagi), zarówno w zakresie jakości życia, jak i rozwoju, cytując: Będac lud ď́mi ponvinniśmy jakość jyycia

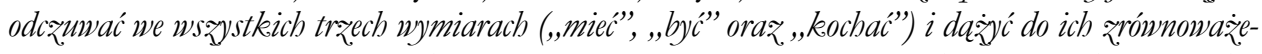
nia. Osiagniecie zrónnoważonej jak ości ṡycia uymaga m.in. zrónnoważonej konsumpcii, która jest skorelowana z. Zachowaniami ekologicznymi konsumentów i ich swriadomościa w tym zakeresie [Kryk, 2013, s. 7]. Poznaniu tych zachowań służyły badania opisane w niniejszym artykule.

Badania ankietowe polegały na analizie zgodności zachowań konsumenckich z koncepcją zrównoważonej konsumpcji. Ich celem była próba odpowiedzi na dwa pytania: 
w jakim stopniu mieszkańcy województwa śląskiego realizują zasady zrównoważonej konsumpcji? oraz jakie czynniki są sprzyjające bądź stanowią barierę dla dokonywania zrównoważonych wyborów konsumpcyjnych?

W badaniach przeprowadzonych we wrześniu 2014 roku wzięło udział 500 pełnoletnich mieszkańców województwa śląskiego. Próba reprezentatywna obejmowała kwotową reprezentację populacji pod względem podstawowych zmiennych demograficznych. Kwestionariusz badawczy składał się z czterdziestu pytań pogrupowanych w czterech blokach tematycznych. Przeprowadzone badania ankietowe były próbą zasygnalizowania pewnych problemów, które wiążą się z konsumpcja gospodarstw domowych, posłużyły podkreśleniu wagi różnorodnych instrumentów w kształtowaniu zrównoważonej konsumpcji, jak również ukazaniu zapatrywań mieszkańców województwa śląskiego na zagadnienia zrównoważonej konsumpcji.

\section{Charakterystyka schematu doboru próby}

Próba reprezentatywna została dobrana w losowaniu warstwowym i dwuetapowym. Pierwszym etapem był dobór próby ze względu na wielkość miejscowości w stosunku do całego województwa śląskiego - zastosowano losowy dobór punktów realizacji. Mieszkańców podzielono na warstwy według klasy miejscowości zamieszkania, wyróżniając: bardzo duże miasta (powyżej 200 tys. mieszkańców), duże miasta (powyżej 100 tys. mieszkańców), średnie miasta (powyżej 50 tys. mieszkańców), małe miasta (powyżej 20 tys. mieszkańców), bardzo małe miasta (poniżej 20 tys. mieszkańców) oraz wsie. Drugą warstwę stanowiły kryteria demograficzne, tj.: płeć, wiek i wykształcenie. W klasyfikacji ze względu na wiek wyróżniono sześć grup wiekowych (19-29 lat, 30-39 lat, 40-49 lat, 50-59 lat, 60-69 lat, 70 lat i więcej). W klasyfikacji ze względu na poziom wykształcenia wyodrębniono cztery kategorie: gimnazjalne i podstawowe ukończone, zasadnicze zawodowe, policealne i średnie oraz wyższe. Dodatkowo, wyszczególniono następujące kryteria klasyfikacji członków gospodarstw domowych:

- stan cywilny,

- liczba osób w gospodarstwie domowym,

- subiektywna ocena sytuacji materialnej,

- status społeczny (uczeń/student, pracujący, bezrobotny, rencista/emeryt, inne, np. rolnik).

Informacje na temat ludności województwa śląskiego pochodziły z Rocznika Statystycżnego Województwa Ślaskiego 2013 [Rocznik Statystycży..., 2013]. Badanie realizowano metodą wywiadów bezpośrednich kwestionariuszowych PAPI w rejonie zamieszkania respondentów.

\section{Kwestionariusz badawczy}

Bloki tematyczne wyodrębnione w kwestionariuszu badawczym dotyczyły: konsumpcji żywności, konsumpcji związanej z wyposażeniem i utrzymaniem mieszkania, kon- 
sumpcji związanej z wykorzystaniem transportu oraz ogólnych zagadnień obejmujących konsumpcję. Uzupełnieniem kwestionariusza była metryczka. Zbiorcze zestawienie tych pytań przedstawia tabela 1. Były to w większości pytania zamknięte (z wykorzystaniem skali Likerta) oraz półotwarte.

Obszary konsumpcji zostały wybrane ze względu na ich silną presję na środowisko. Jest to zgodne z wynikami badań Komisji Europejskiej (projekt badania wpływu produktów na środowisko - EIPRO) [EEA, 2007]. Lacznie te trzy dziedziny konsumpcji odpowiadaja za $70-80 \%$ wpływów na środowisko oraz pochłaniają $60 \%$ wydatków konsumpcyjnych. Dodatkowo, w obszarze związanym z konsumpcją żywności autorka zbadała aspekt etyczny konsumpcji na przykładzie pytania dotyczącego informacji o sposobie chowu kur (umieszczonej na kupowanych jajkach). Ponadto, w tym obszarze, jak również w dwóch pozostałych, autorka za pomocą odpowiednich pytań zmierzała do poznania motywów, jakimi kierują się ludzie przy wyborze określonych sposobów zaspokojenia potrzeb (pytania m.in.: 7., 9., 15., 17., 31., 32., 34., 40.).

TABELA 1.

\section{Rozkład pytań kwestionariusza ankietowego}

\begin{tabular}{|c|c|}
\hline Lp. & Pytania \\
\hline \multicolumn{2}{|c|}{ I Konsumpcja żywności - liczba pytań: 10} \\
\hline 1. & $\begin{array}{l}\text { Jaki jest, Twoim zdaniem, związek między jakością spożywanej żywności a stanem śro- } \\
\text { dowiska naturalnego? }\end{array}$ \\
\hline 2. & $\begin{array}{l}\text { Czy zwracasz uwagę na informację o sposobie chowu kur umieszczoną na kupo- } \\
\text { wanych jajkach? }\end{array}$ \\
\hline 3. & $\begin{array}{l}\text { Czy masz zaufanie do tzw. zdrowej żywności (np. sprzedawanej w sklepach ze zdrową } \\
\text { żywnościa), że rzeczywiście pochodzi z wiarygodnego źródła? }\end{array}$ \\
\hline 4. & $\begin{array}{l}\text { Jak często kupujesz żywność fair trade (oznacza żywność pochodzacca ze sprawiedliwe- } \\
\text { go handlu, gdzie pracownicy mają zapewnione godziwe warunki płacy i pracy)? }\end{array}$ \\
\hline 5. & Jak często jesz mięso/wędlinę? \\
\hline 6. & $\begin{array}{l}\text { Czy starasz się kupować żywność wyprodukowaną w pobliżu Twojego miejsca za- } \\
\text { mieszkania? }\end{array}$ \\
\hline 7. & $\begin{array}{l}\text { Wybieram żywność wyprodukowaną w pobliżu mojego miejsca zamieszkania, ponie- } \\
\text { waż: (kafeteria odpowiedzi). }\end{array}$ \\
\hline 8. & $\begin{array}{l}\text { W poniższej tabeli zakreśl stwierdzenia najlepiej oddające twoje zachowanie: (kafeteria } \\
\text { odpowiedzi). }\end{array}$ \\
\hline 9. & Kupując żywność, kieruje się przede wszystkim: (kafeteria odpowiedzi). \\
\hline 10. & Czy kupujesz żywność bezpośrednio u lokalnych rolników? \\
\hline \multicolumn{2}{|r|}{$\begin{array}{l}\text { II Konsumpcja związana z wyposażeniem i utrzymaniem mieszkania - liczba py- } \\
\text { tań: } 15\end{array}$} \\
\hline 11. & Ile $\mathrm{m}^{2}$ przypada na 1 osobę w Twoim gospodarstwie domowym? \\
\hline 12. & Proszę podaj sposób ogrzewania Twojego domu? \\
\hline 13. & Czy segregujesz odpady? \\
\hline 14. & Jakie odpady oddzielasz od innych podczas segregacji? \\
\hline 15. & Co jest głównym powodem tego, że segregujesz odpady? \\
\hline
\end{tabular}




\begin{tabular}{|c|c|}
\hline 16. & Jak często korzystasz podczas zakupów z toreb wielokrotnego użytku? \\
\hline 17. & Jaka jest, Twoim zdaniem, główna idea korzystania z toreb wielokrotnego użytku? \\
\hline 18. & Czy zwykle zostawiasz na dłużej, np. na noc, urządzenia RTV w trybie czuwania? \\
\hline 19. & Czy, Twoim zdaniem, w Twoim gospodarstwie domowym oszczędza się wodę? \\
\hline 20. & $\begin{array}{l}\text { Czy, Twoim zdaniem, w Twoim gospodarstwie domowym oszczędza się energię } \\
\text { elektryczną? }\end{array}$ \\
\hline 21. & $\begin{array}{l}\text { Jaka temperatura pomieszczeń mieszkalnych (jadalnia, pokój dzienny) jest, Twoim } \\
\text { zdaniem, optymalna w zimie? }\end{array}$ \\
\hline 22. & Czy taką temperaturę utrzymujesz w swoim domu? \\
\hline 23. & Jaką temperaturę preferujesz w sypialni? \\
\hline 24. & Czy masz zainstalowane w domu urządzenia oszczędzające wodę? \\
\hline 25. & Jak często, Ty osobiście, starasz się oszczędzać energię elektryczną? \\
\hline \multicolumn{2}{|r|}{ III Konsumpcja związana z wykorzystaniem transportu - liczba pytań: 11} \\
\hline 26. & Jaka jest odległość Twojego miejsca zamieszkania od miejsca pracy? \\
\hline 27. & Jakim środkiem transportu dojeżdżasz do pracy? \\
\hline 28. & Jakim środkiem transportu dojeżdżasz na zakupy? \\
\hline 29. & Czy posiadasz samochód? \\
\hline 30. & Czy posiadasz prawo jazdy? \\
\hline 31. & $\begin{array}{l}\text { Jakie sa, Twoim zdaniem, główne przyczyny przedkładania samochodu nad inne } \\
\text { środki transportu? }\end{array}$ \\
\hline 32. & Jakie są Twoim zdaniem, główne korzyści płynące z wyboru transportu publicznego? \\
\hline 33. & $\begin{array}{l}\text { Czy poparł(a)byś wprowadzenie w miastach specjalnie wydzielonych pasów jezdni dla } \\
\text { pojazdów transportu publicznego, nawet jeśli wiązałoby się to z wprowadzeniem } \\
\text { ograniczeń w indywidualnym ruchu samochodowym? }\end{array}$ \\
\hline 34. & W jakim celu najczęściej korzystasz z roweru? \\
\hline 35. & Gdzie spędziłeś/spędziłaś ostatnio dłuższy urlop? \\
\hline 36. & Jak często jako środek transportu do miejsca przeznaczenia wybierasz samolot? \\
\hline \multicolumn{2}{|r|}{ IV Ogólne zagadnienia dotyczące konsumpcji - liczba pytań: 4} \\
\hline 37. & $\begin{array}{l}\text { W poniższej tabeli zakreśl stwierdzenia najlepiej oddające Twoje zachowanie: (kafete- } \\
\text { ria odpowiedzi). }\end{array}$ \\
\hline 38. & Czego najbardziej w chwili obecnej Ci brakuje? \\
\hline 39. & Czy uważasz, że Twoja konsumpcja jest zrównoważona? \\
\hline 40. & Jakie są główne przeszkody w prowadzeniu zrównoważonej konsumpcji? \\
\hline
\end{tabular}

Źródło: opracowanie własne na podstawie: [Badania ankietowe, 2014].

\section{Omówienie wyników badania}

Analiza odpowiedzi mieszkańców województwa śląskiego na pytania zawarte w ankiecie pozwoliła na sformułowanie poniższych wniosków (istotnych z punktu widzenia implementacji idei zrównoważonej konsumpcji w Polsce $)^{1}$.

\footnotetext{
${ }^{1}$ Z uwagi na ograniczoną objętość niniejszego artykułu autorka pozwoliła sobie jedynie na przytoczenie najciekawszych poznawczo wniosków.
} 
Celem badania było poznanie, czy mieszkańcy województwa śląskiego realizują zrównoważoną konsumpcję. W związku z tym, zapytano mieszkańców wprost, czy uważaja, że ich konsumpcja jest zrównoważona (rysunek 1.). Odpowiedzi przeczące przeważały nad odpowiedziami twierdzącymi (aż 31,4 proc. badanych udzieliło zdecydowanej odpowiedzi negatywnej („moja konsumpcja nie jest zrównoważona”), podczas gdy 14,6 proc. odpowiedzi stanowczo pozytywnej („moja konsumpcja jest zrównoważona”). Dla dość dużej grupy badanych pojęcie zrównoważonej konsumpcji mogło stanowić nowość, o czym świadczyło istnienie dużej grupy (22,8 proc. ogółu populacji) niepotrafiącej określić, czy jej konsumpcja jest zrównoważona, czy też nie („nie mam zdania”).

RYSUNEK 1.

\section{Rozkład odpowiedzi na pytanie: „Czy uważasz, że Twoja konsumpcja jest zrównoważona?”}

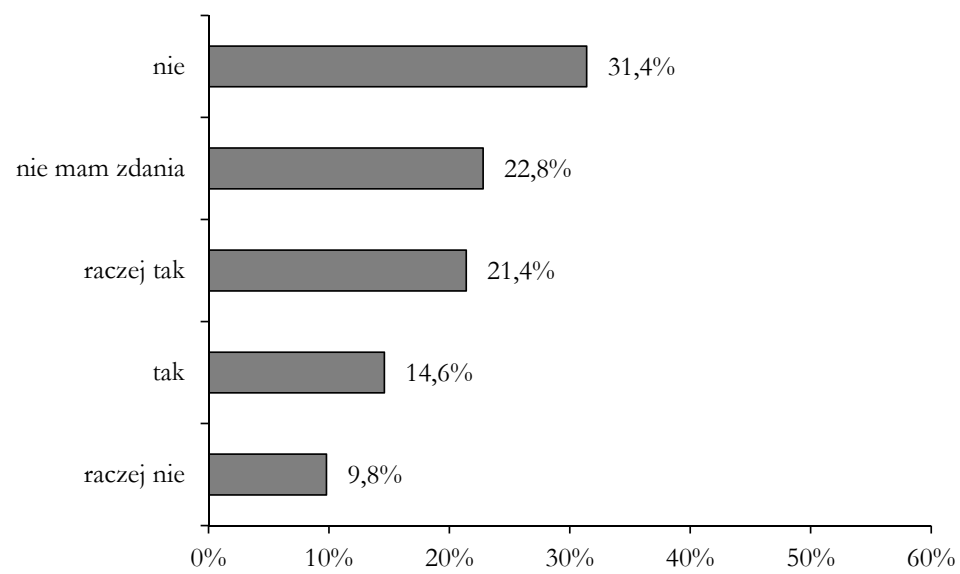

Źródło: opracowanie własne na podstawie: [Badania ankietowe, 2014].

Jak pokazała analiza odpowiedzi pod kątem charakterystyki mieszkańców, istnieje bardzo silne zróżnicowanie mieszkańców województwa śląskiego w zależności od: miejsca zamieszkania, wykształcenia oraz sytuacji materialnej postrzeganej przez respondentów. Jednocześnie pozostałe pytania ankiety dostarczyły pośrednich informacji, na podstawie których można wnioskować, w jakim stopniu badani mieszkańcy rzeczywiście realizują postulaty zrównoważonej konsumpcji. Nie zaobserwowano, ażeby subiektywne odczucia respondentów pokrywały się z przejawianymi zachowaniami. W pewnych obszarach to właśnie mieszkańcy wsi, którzy częściej uważali, że ich konsumpcja nie jest zrównoważona, przejawiali bardziej zrównoważone zachowania (np.: częściej niż mieszkańcy miast starali się kupować napoje w opakowaniach zwrotnych; częściej zwracali uwage na to, aby produkt posiadał certyfikat ekologiczny; częściej segregowali odpady). Wykształcenie jest drugim z czynników silnie różnicującym to, jak osoby postrzegają swoją konsumpcję. Osoby, które udzielały odpowiedzi twierdzących, to w głównej mierze mieszkańcy legitymujący się wykształceniem średnim oraz wyższym. Osoby, które uważały, że ich konsumpcja nie jest bądź raczej nie jest zrównoważona, to osoby posiadające 
wykształcenie podstawowe, zawodowe oraz policealne. Tym niemniej, analizując odpowiedzi poszczególnych grup społecznych, można zauważyć, że taki rozkład odpowiedzi może wynikać z niewiedzy na temat zrównoważonej konsumpcji, gdyż to właśnie osoby z wyższym wykształceniem w niektórych obszarach przejawiały mniej zrównoważone zachowania (np.: rzadziej korzystały z toreb wielokrotnego użytku, częściej korzystały z przelotów samolotowych, w mniejszym stopniu niż pozostałe grupy deklarowały oszczędzanie energii i wody). Ostatnim z czynników silnie różnicującym mieszkańców pod kątem postrzegania własnej konsumpcji była odczuwana sytuacja materialna. Można tu zaobserwować następującą prawidłowość - wraz ze wzrostem zamożności mieszkańców wzrastała skłonność do uznawania swojej konsumpcji na zrównoważona. Oznacza to, że osoby, odbierające swoją sytuację materialną jako korzystna, zdecydowanie częściej wskazywały, że ich konsumpcja jest zrównoważona aniżeli osoby, które uważały, że ich dochód jest niewystarczający. Wśród osób o najgorszej sytuacji materialnej najwięcej było także osób niezdecydowanych, które nie miały zdania na ten temat (33 proc. osób, których „dochód pozwala zaspokoić tylko podstawowe potrzeby” oraz aż 47 proc. w grupie osób, których „dochód jest w ogóle niewystarczający”).

Ponad połowa osób utrzymywała, że istnieje silny bądź raczej silny związek między jakością spożywanej żywności a stanem środowiska naturalnego, jednocześnie duża była grupa oceniających ten związek jako słaby bądź raczej słaby (w ten sposób sądził prawie co trzeci badany) (rysunek 2.). Mieszkańcy wsi zdecydowanie częściej niż mieszkańcy dużych miast wyrazili opinię, że związek ten jest silny.

RYSUNEK 2.

Rozkład odpowiedzi na pytanie: „Jaki jest, Twoim zdaniem, związek między jakością spożywanej żywności a stanem środowiska naturalnego?”

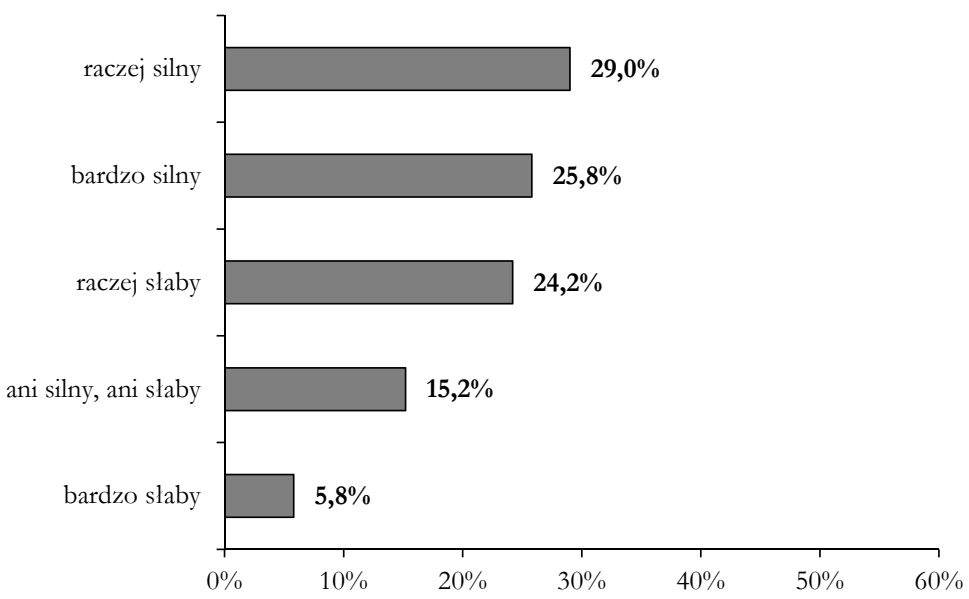

Źródło: opracowanie własne na podstawie: [Badania ankietowe, 2014]. 
O istnieniu braków w zrównoważonych nawykach żywieniowych świadczy przewaga odpowiedzi negatywnych na pytanie związane $z$ informacja o sposobie chowu kur umieszczonej na kupowanych jajkach (rysunek 3.) czy brakiem skłonności do kupowania żywności fair trade (rysunek 4.). Na niezrównoważone nawyki konsumpcyjne wskazała również zdecydowana przewaga osób często spożywających produkty mięsne. Pozytywne nawyki żywieniowe były kojarzone ze skłonnością do wybierania żywności wyprodukowanej w pobliżu miejsca zamieszkania respondentów oraz do kupowania żywności od lokalnych rolników (czyniło tak prawie 3/4 badanych).

RYSUNEK 3.

Rozkład odpowiedzi na pytanie: „Czy zwracasz uwagę na informację o sposobie chowu kur umieszczoną na kupowanych jajkach?”

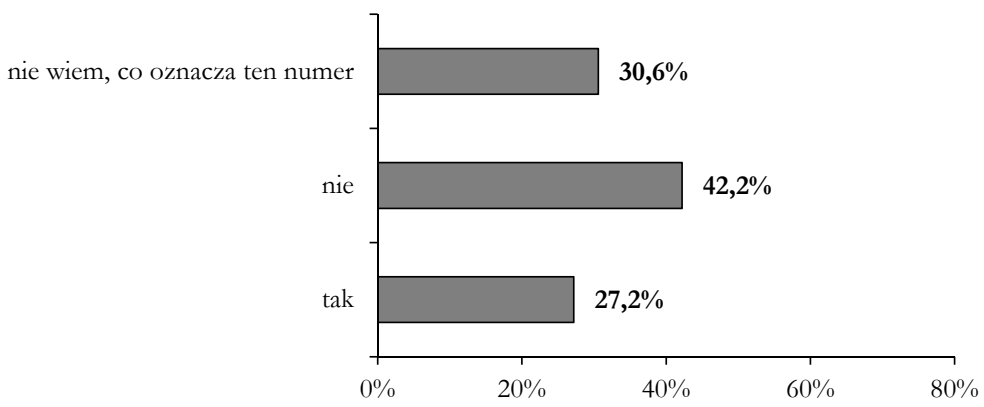

Źródło: opracowanie własne na podstawie: [Badania ankietowe, 2014].

RYSUNEK 4.

Rozkład odpowiedzi na pytanie: „Jak często kupujesz żywność fair trade (oznaczającą żywność pochodzącą ze sprawiedliwego handlu, gdzie pracownicy mają zapewnione godziwe warunki płacy i pracy)?”

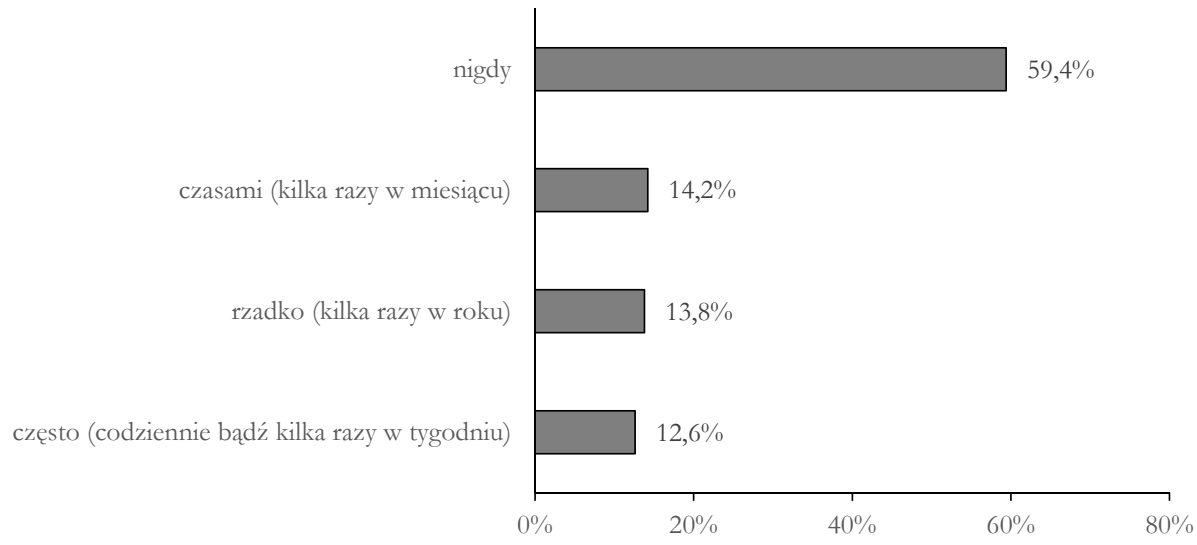

Źródło: opracowanie własne na podstawie: [Badania ankietowe, 2014]. 
Czynnikiem utrudniającym dokonywanie zrównoważonych żywieniowych wyborów konsumpcyjnych był wyższy koszt (cena) zdrowej, ekologicznej żywności w porównaniu z jej tradycyjnymi odpowiednikami. Zdecydowana większość ankietowanych (80,2 proc.) podczas zakupu żywności kierowała się przede wszystkim ceną (rysunek 5.).

RYSUNEK 5.

\section{Rozkład odpowiedzi na pytanie o główne motywy wyboru żywności (respondenci mogli wskazać trzy najistotniejsze motywy)}

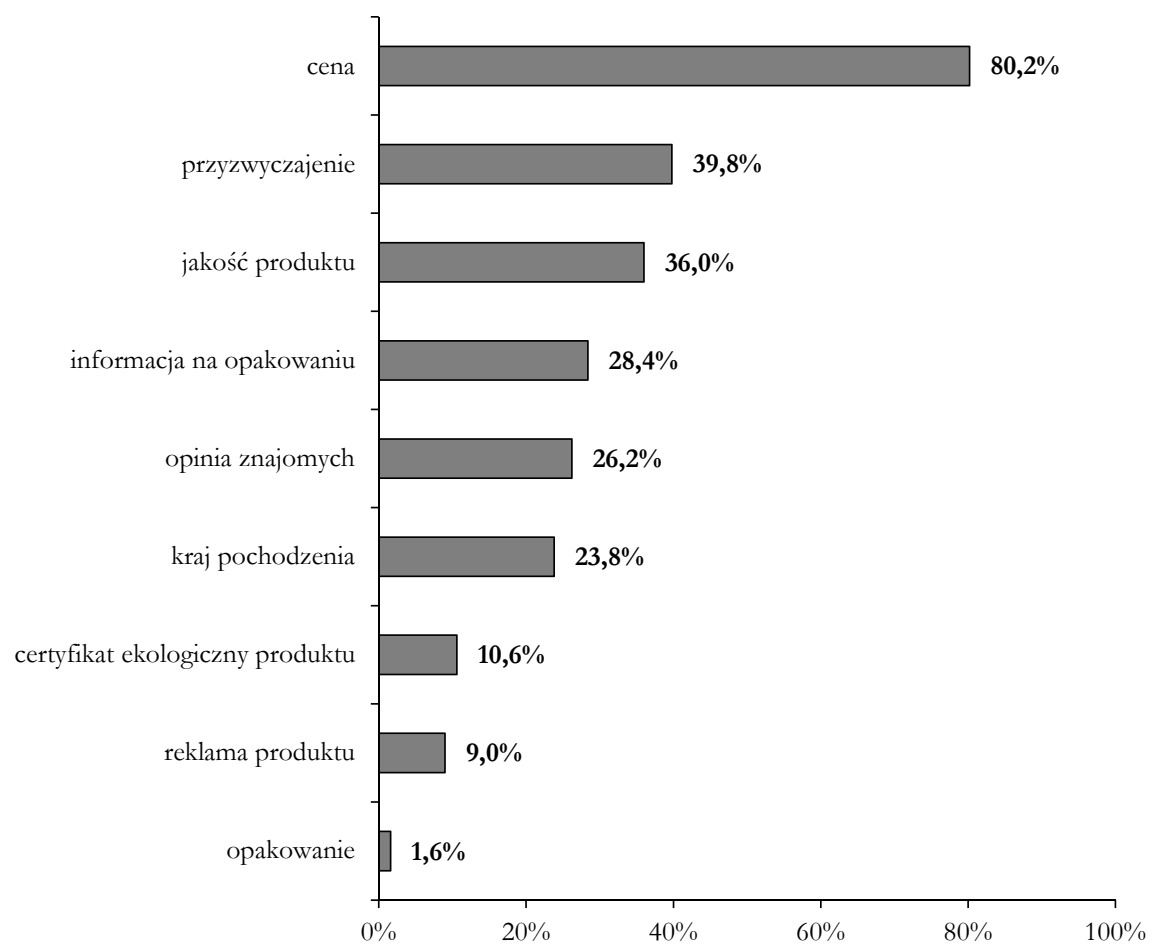

Źródło: opracowanie własne na podstawie: [Badania ankietowe, 2014].

Za korzystną tendencję należy uznać wysoką skłonność do wykorzystania toreb wielokrotnego użytku podczas zakupów (postępowało tak zawsze bądź często 80,2 proc.), która została przedstawiona na rysunku 6. Główne korzyści osiagane dzięki używaniu toreb wielokrotnego użytku można podzielić na: osobiste (zaoszczędzenie pieniędzy) oraz na motywowane dbałością o środowisko (przyczynienie się do zmniejszenia ilości odpadów oraz ochrona środowiska naturalnego). Te pierwsze ważne były dla 46,4 proc., a drugie dla 52,4 proc. mieszkańców. 
RYSUNEK 6.

\section{Rozkład odpowiedzi na pytanie: „Jak często podczas zakupów korzystasz $\mathrm{z}$ toreb wielokrotnego użytku?"}

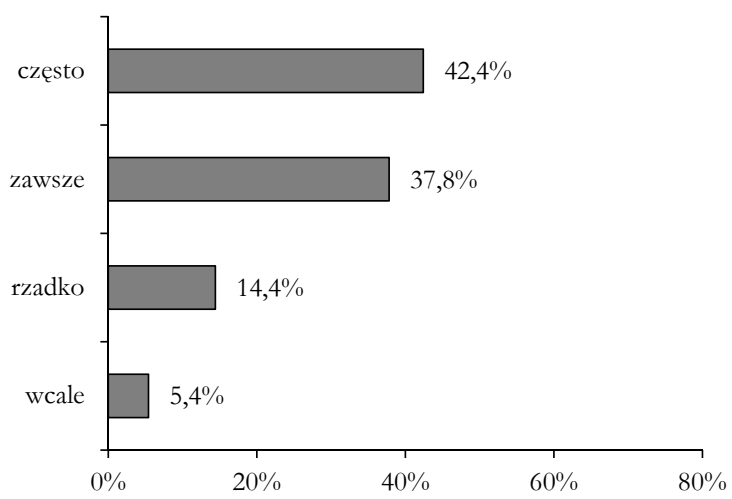

Źródło: opracowanie własne na podstawie: [Badania ankietowe, 2014].

Około 3/4 respondentów segregowało odpady (rysunek 7.). Najczęściej podawanym powodem przez 70,2 proc. była chęć ochrony środowiska naturalnego. Motyw ekonomiczny (,tak jest taniej”) był ważny dla 57,1 proc. badanych. Choć tak wielu ankietowanych wymieniało jako główny powód segregacji chęć ochrony środowiska naturalnego, jednocześnie tak niewielu podawało, że segregowało przeterminowane lekarstwa (czyniło tak zaledwie 4 proc.), a właśnie niewłaściwie zutylizowane lekarstwa (czyli np. wylane do kanalizacji) przyczyniają się do niebezpiecznego zanieczyszczenia środowiska.

RYSUNEK 7.

\section{Rozkład odpowiedzi na pytanie: „Co jest głównym powodem tego,} że segregujesz odpady?”

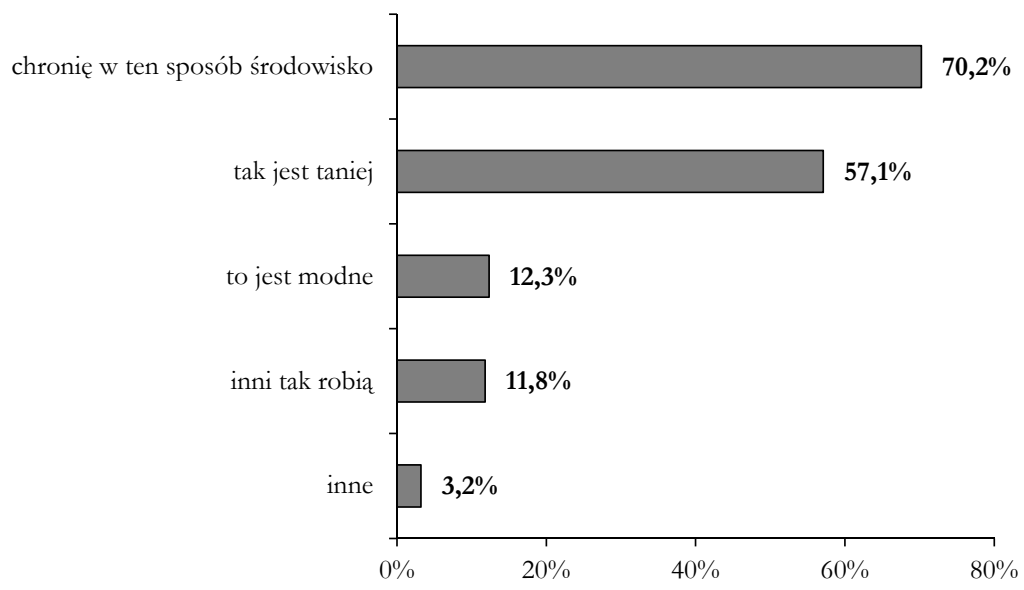

Źródło: opracowanie własne na podstawie: [Badania ankietowe, 2014]. 
Pozytywnym zachowaniem deklarowanym przez zdecydowaną większość respondentów było oszczędzanie wody oraz energii. Tym niemniej w praktyce tylko co czwarty mieszkaniec oświadczył, że nie pozostawia na dłużej urządzeń RTV w trybie czuwania. Pytanie, które pozwoliło również stwierdzić, jak w praktyce wygląda oszczędność energii, było związane $z$ temperaturą utrzymywana $w$ okresie zimowym $w$ pomieszczeniach mieszkalnych. Przeważająca większość respondentów preferowała temperatury wyższe od temperatur uznawanych za optymalne dla zdrowia, jak również przynoszących korzyści dla środowiska w postaci zmniejszonego zużycia energii.

Ważnym motywem decydującym o zachowaniu mieszkańców był motyw ekonomiczny („coś jest tańsze, ponosi się mniejsze koszty” itp.).

W obszarze promowania zrównoważonych sposobów przemieszczania się jest konieczne zapewnienie: dogodnych, bezpiecznych oraz korzystnych cenowo środków transportu publicznego, jeśli zmierza się do odciążenia prywatnego ruchu samochodowego. Nie należy oczekiwać, że w naszym klimacie znacząco może wzrosną́ wykorzystanie roweru jako środka transportu. Prawie połowa mieszkańców w ogóle tego nie czyniła, a ta grupa, która to robiła, sugerowała się głównie rekreacja.

Większość respondentów nigdy (blisko 70 proc. ogółu) bądź prawie wcale (13,6 proc.) nie korzystała z przelotów samolotowych. Napawa to optymizmem, chociaż należy zauważyć, że wraz ze wzrostem zamożności, wzrastała skłonność do podróży lotniczych.

W jednym z pytań poproszono respondentów o wskazanie podstawowych przeszkód w prowadzeniu zrównoważonej konsumpcji, a także o określenie wagi przeszkody, gdzie 1 oznaczało najistotniejszy powód, a 5 powód najmniej znaczący. Wyniki przedstawiono w tabeli 2.

TABELA 2.

Rozkład odpowiedzi na pytanie: „Jakie są główne przeszkody w prowadzeniu zrównoważonej konsumpcji?”

\begin{tabular}{|l|r|r|r|r|r|c|}
\hline \multirow{2}{*}{$\begin{array}{c}\text { Jakie są główne przeszkody } \\
\text { w prowadzeniu zrównowa- } \\
\text { żonej konsumpcji? }\end{array}$} & \multicolumn{6}{|c|}{ 1 - najistotniejszy powód, 5 - najmniej istotny powód } \\
\cline { 2 - 7 } & $\mathbf{1}$ & $\mathbf{2}$ & $\mathbf{3}$ & \multicolumn{1}{c|}{$\mathbf{4}$} & $\mathbf{5}$ & \multicolumn{1}{c|}{ średnia } \\
\hline Wymaga za dużo czasu & $55,6 \%$ & $21,0 \%$ & $12,6 \%$ & $4,4 \%$ & $6,4 \%$ & $\mathbf{1 , 9}$ \\
\hline Wymaga za dużo wysiłku & $47,6 \%$ & $23,8 \%$ & $14,8 \%$ & $5,8 \%$ & $8,0 \%$ & $\mathbf{2 , 0}$ \\
\hline Jest za droga & $68,8 \%$ & $11,0 \%$ & $7,6 \%$ & $4,4 \%$ & $8,2 \%$ & $\mathbf{1 , 7}$ \\
\hline $\begin{array}{l}\text { Nie ma takich produktów na } \\
\text { rynku }\end{array}$ & $11,4 \%$ & $25,2 \%$ & $23,0 \%$ & $14,8 \%$ & $25,6 \%$ & $\mathbf{3 , 2}$ \\
\hline Brak informacji, jak to robić & $39,0 \%$ & $21,8 \%$ & $16,0 \%$ & $14,0 \%$ & $9,2 \%$ & $\mathbf{2 , 3}$ \\
\hline Inni tego nie robią & $6,8 \%$ & $7,0 \%$ & $16,2 \%$ & $21,8 \%$ & $48,2 \%$ & $\mathbf{4 , 0}$ \\
\hline
\end{tabular}

Źródło: opracowanie własne na podstawie: [Badania ankietowe, 2014].

Na podstawie odpowiedzi wyciagnięto średnią z poszczególnych wag (rysunek 8.). Najistotniejszą przeszkodą w prowadzeniu zrównoważonej konsumpcji okazał się dla mieszkańców województwa śląskiego jej koszt. Była to najistotniejsza przeszkoda głównie dla mieszkańców wsi i najmniejszych miasteczek, oraz, co oczywiste, osób w najgorszej sytuacji materialnej. Stąd można przypuszczać, że mieszkańcy nie do końca dobrze 
rozumieją istotę zrównoważonych zachowań konsumpcyjnych. Można również domyślać się, że dla sporej grupy respondentów zrównoważona konsumpcja była za droga, gdyż kojarzyła się przede wszystkim z większymi wydatkami bieżącymi na zakup np.: ekologicznej żywności, urządzeń energooszczędnych. Jednocześnie konsumenci zdali się zapominać o pozytywnych skutkach i oszczędnościach możliwych do uzyskania w dłuższym okresie dzięki oszczędności energii, wody, efektywniejszemu użytkowaniu przedmiotów. Kolejną ważną przeszkodą, którą jako najważniejszy powód wskazała ponad połowa badanych, była konieczność przeznaczania większej ilości czasu na zachowania konsumpcyjne. Badani chcieli przez to podkreślić, że konsumpcja zrównoważona zabiera więcej czasu aniżeli zwykła, standardowa konsumpcja. Była to najistotniejsza przeszkoda dla osób znajdujących się w dobrej sytuacji materialnej. Niemniej istotny okazał się wysiłek, jaki należy włożyć, ażeby praktykować zrównoważoną konsumpcję - przeszkoda ta okazała się bardzo ważna dla 47,6 proc. badanych. Duża grupa respondentów podkreślała również zasadnicze znaczenie braku informacji na temat sposobów praktykowania zrównoważonej konsumpcji. Najmniej ważne okazały się dwie przeszkody związane z dostępnością produktów zrównoważonych na rynku oraz z niezauważaniem tego typu zachowań u innych.

RYSUNEK 8.

Rozkład odpowiedzi na pytanie: „Jakie są główne przeszkody w prowadzeniu zrównoważonej konsumpcji? (proszę przyporządkować: 1 - najistotniejszy powód, 5 - najmniej istotny?)"

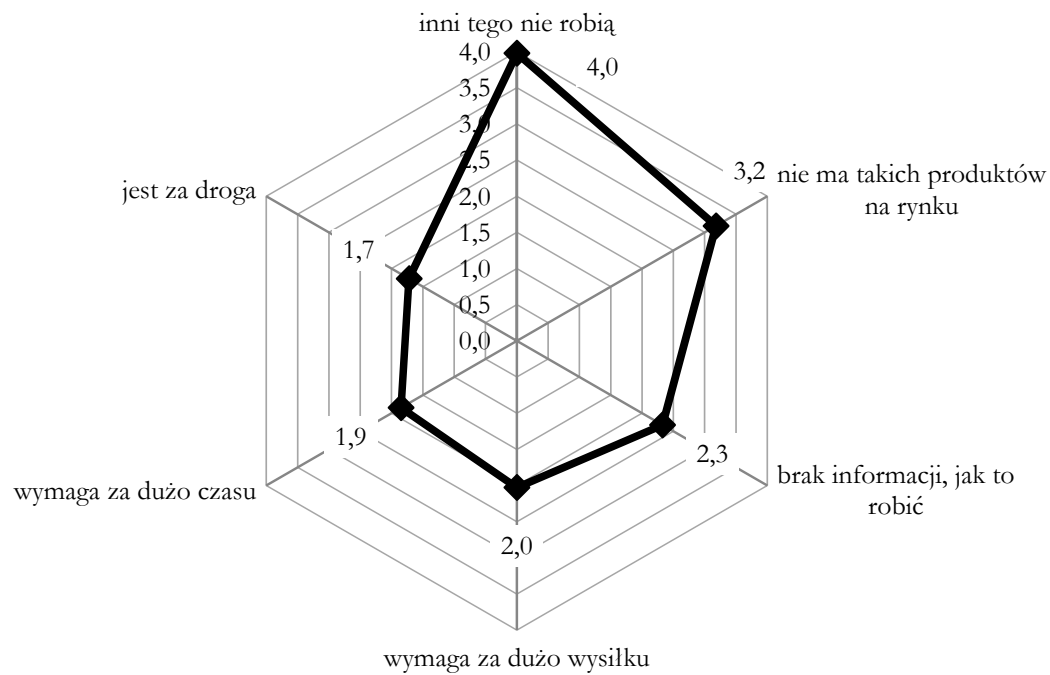

Źródło: opracowanie własne na podstawie: [Badania ankietowe, 2014]. 
W chwili obecnej mieszkańcom województwa śląskiego najbardziej brakuje poprawy sytuacji materialnej. Znaczna jest grupa osób, która uznała swoją sytuację materialną za niezadowalająca. Jak można było spodziewać się, te osoby wskazały właśnie brak pieniędzy jako najpilniejszy problem. Na ten także częściej powoływały się osoby z wykształceniem zasadniczym zawodowym oraz podstawowym.

\section{Podsumowanie}

Przeprowadzone badanie ankietowe pokazało, że mieszkańcy województwa śląskiego w sposób zróżnicowany realizowali zasady zrównoważonej konsumpcji.

Subiektywne postrzeganie konsumpcji przez respondentów jest znacznie zróżnicowane - czynnikami silnie skorelowanymi byly: miejsce zamieszkania (konsumenci największych miast uznawali swoją konsumpcję za raczej zrównoważona), wykształcenie (wraz ze wzrostem wykształcenia zwiększało się zapatrywanie na własną konsumpcję jako zrównoważona) oraz odczuwana sytuacja materialna (wraz z poprawą sytuacji materialnej wzrastało przekonanie o własnej konsumpcji jako bardziej zrównoważonej). Tym niemniej nie zaobserwowano, ażeby subiektywne odczucia respondentów pokrywały się z rzeczywistymi działaniami; w pewnych obszarach to właśnie mieszkańcy wsi, którzy zdecydowanie częściej uważali, że ich konsumpcja nie jest zrównoważona, przejawiali bardziej zrównoważone zachowania; podobna sytuacja dotyczyła osób z wykształceniem wyższym i średnim, które zważywszy na deklarowany, wysoki stopień zrównoważenia konsumpcji, w rzeczywistości nie przejawiały w widoczny sposób bardziej zrównoważonych zachowań; w związku z tym autorka sądzi, że taki rozkład odpowiedzi może wynikać z niewiedzy na temat zrównoważonej konsumpcji.

Zauważono wykazywanie przez respondentów ambiwalentnych postaw wobec zasad zrównoważonej konsumpcji - na przykład respondenci z jednej strony deklarowali, że oszczędzają energię, a z drugiej najczęściej pozostawiali urządzenia RTV w trybie czuwania; z jednej strony segregowali odpady powodowani chęcią ochrony środowiska, a z drugiej w znikomym stopniu segregowali lekarstwa.

Badanie pokazało, że zrównoważona konsumpcja nie jest w pełni zrozumiała, czego dowodem było wskazywanie przez zdecydowaną większość kosztów materialnych jako głównej bariery w prowadzeniu zrównoważonej konsumpcji (,jest za droga"); z kolei dla osób o najwyższych dochodach zasadnicza przeszkodą w prowadzeniu zrównoważonej konsumpcji okazał się brak czasu (,wymaga za dużo czasu”).

Na podstawie wyników badania można stwierdzić, że korzystnym czynnikiem sprzyjającym dokonywaniu zrównoważonych wyborów konsumpcyjnych jest równoczesny wzrost zasobności oraz świadomości na temat wpływu człowieka na środowisko. Wzrost świadomości jest możliwy w wyniku zastosowania instrumentów informacyjno-edukacyjnych równoważenia konsumpcji. Pozytywną rolę odgrywają zarazem instrumenty administracyjno-prawne (przykładem są wprowadzone uregulowania z zakresu gospodarki odpadami) oraz instrumenty ekonomiczno-rynkowe (mimo iż, jak pokazało badanie, większość osób nie zdawała sobie sprawy z tego, że posiada w domu urządzenia oszczędzające wodę, to właśnie te urządzenia, tj. wodomierze czy perlatory w bateriach łazienkowych, 
przyczyniały się do zmniejszonego zużycia wody). Te trzy powyższe grupy instrumentów należą, według OECD, do podstawowych narzędzi, dzięki którym jest możliwe wdrażanie zasad zrównoważonej konsumpcji [OECD, 2002]. Wyniki ankiety pozwalają jednocześnie przypuszczać, że część mieszkańców nie wie, w jaki sposób praktykować zrównoważoną konsumpcję, tak aby przynosiła ona korzyści materialne w postaci zwiększonych oszczędności czy korzyści niematerialnych związanych ze spotęgowaną satysfakcją z życia i lepszym zdrowiem.

\section{Literatura}

Allardt E., 1993, Having, Loving, Being: An Alternative to the Swedish Model of Welfare Research, [in:] The Quality of Life, M. Nussbaum, A. Sen (eds.), Oxford University Press, Oxford.

Badania ankietowe, 2014, przeprowadzone w sierpniu oraz wrześniu 2014 roku wśród 500 pełnoletnich mieszkańców województwa śląskiego powyżej 19. roku życia.

Borys T., 2014, Wybrane problemy metodologï pomiaru nowego paradygmatu rozwoju - polskie doświadczenia, ,, Optimum. Studia Ekonomiczne”, nr 3(69).

EEA (European Environment Agency), 2007, Środowisko Europy. Czwarty Raport Oceny, no. 2, http://www.eea.europa. eu/pl/publications/state_of_environment_report_ 2007_2 (data wejścia: 21.03.2014).

Kiełczewski D., 2008, Konsumpcja a perspektywy zrównoważonego rozwoju, Wydawnictwo Uniwersytetu w Białymstoku, Białystok.

Kryk B., 2013, Zrównoważona jakość życia a zrównoważona konsumpcja i zachowania ekologiczne polskich konsumentów, „Handel Wewnętrzny”, nr 6 A, t. 2.

OECD, 2002, Towards Sustainable Household Consumpton? Trends and Policies in OECD Countries, Policy Brief, July 2002, www.oecd.org/greengrowth/consumption-innovation/1938984.pdf (data wejścia: 19.01.2015).

Oslo Rountable on Sustainable Production and Consumption, 1994, http://www.iisd.ca/consume/ oslo004.html\#top (data wejścia: 21.10.2015).

Rocznik Statystyczny Województwa Ślaskiego 2013, 2013, http:/ / katowice.stat.gov.pl/ publikacje-i-foldery/roczniki-statystyczne/rocznik-statystyczny-wojewodztwa-slaskiego-2013,4,13.html (data wejścia: 30.06.2014). 